\title{
Analytical review of issues of creation of the agro-digital cooperation platform as an economic mechanism for sustainable development of agricultural production
}

\author{
E.F. Amirova ${ }^{1}$, A.L. Zolkin ${ }^{2, *}$, P.M. Podolko ${ }^{3}$, E.I. Baldina ${ }^{4}$ and S.N. Kosnikov ${ }^{5}$ \\ ${ }^{1}$ Federal state budgetary educational institution of higher education Kazan State Agrarian University, \\ K.Marx Street 65, 420015 Kazan, Russia \\ ${ }^{2}$ Povolzhskiy State University of Telecommunications and Informatics, L.Tolstogo Street 23, Samara \\ 443010, Russia \\ ${ }^{3}$ Department of Transport, Peoples' Friendship University of Russia (RUDN University), Rabochaya \\ Street 2, Shherbinka, 108851 Moscow, Russia \\ ${ }^{4}$ Federal State Budgetary Educational Institution of Higher Education "Kamyshin Technological \\ University", the branch of the Federal State Budgetary Educational Institution of Higher Education \\ "Volgograd State Technical University", Lenina Street 6a, 403874 Kamyshin, Russia \\ ${ }^{5}$ Federal State Budgetary Educational Institution of Higher Education «Kuban State Agrarian \\ University named after I.T. Trubilin», Kalinina Street 13, 350044 Krasnodar, Russia
}

\begin{abstract}
The article proposes a program to create a digital platform for cooperation and regulation of agricultural production. It is substantiated that the digitalization of the agricultural sector takes place simultaneously in three environments: real (offline) environment, virtual (online) environment, institutional environment. It was revealed that priority projects to ensure sustainable development of agricultural production based on digital technologies ensure the improvement of the regulatory environment, based on the principle of the primacy of sustainable development and digital processes, products and services, the development of ICT infrastructure that meets modern requirements and capabilities, and the provision of an accessible digital education for the population of rural areas and their access to digital technologies, the formation of an agrodigital platform as the core of a nationwide digital business ecosystem.
\end{abstract}

\section{Introduction}

The formation of competitive agricultural production requires the reproduction of the production and resource potential of agricultural enterprises and households on a qualitatively new resource-saving basis. Therefore, the processes of innovative activity in agricultural production should be complex throughout the entire cycle of activity: from education and science to the introduction of an innovative product into real production, and not be reduced to the introduction of individual innovative measures. It shall be noted that

\footnotetext{
* Corresponding author: alzolkin@list.ru
} 
the improvement of agricultural production technology, which is not based on fundamental changes in technology, causes additional complication of equipment and an increase in its cost, which, in turn, reduces the economic efficiency of renewal of labor means. The introduction of the latest technologies ensures the improvement and renewal and productive reproduction of production and resource potential. Scientists consider innovative technology primarily as an organizational innovation. In addition, management activities play an important role in the implementation of innovations, which should smooth out possible contradictions between the technological level of production and the organization of management at the enterprise, and increase the efficiency of innovation processes.

\section{Results}

The work substantiates the creation of a digital platform for cooperation and balancing of agricultural production, the conceptual scheme of which provides for the possibility of combining various groups of individuals and legal entities, residents and non-residents, importers and exporters whose interests are related to the agricultural production sector. The path breakers of the study of the problem of innovation were M. Tugan-Baranovsky and Austrian scientist J.A. Schumpeter, who identified the role of innovation in quality economic growth. B. Santo and B. Twis were their followers. The problems of innovative development of agriculture in Russia have been worked out by the following scientists: Ambrosov V.Ya., Gorbunov M. P., Yatsenko A. N., Shubravskaya A. V., Laiko P. A, Sabluk P. T., Prisyazhnyuk M. V., Kotikova A.I., Pokotilova V.I. and others. The scientific works of these scientists have made a significant contribution to the development of the theory and practice of innovation processes in the agricultural sector of the economy. But in the context of considering these issues in conditions of the requirements of sustainable development and integration, it is the introduction of the agro-digital cooperation platform that will help increase the competitiveness of agricultural production $[1,2]$.

The logical and structural diagram of the agro-digital cooperation platform assumes the presence of a number of blocks that ensure the exchange of information, goods, services and money between user groups, creating added value for them.

The target users of the platform are agricultural producers, rural residents, land owners, consumers of agricultural products, suppliers of fertilizers and fuels and lubricants, manufacturers of agricultural equipment and related software, environmental organizations, portfolio investors, business associations related to agricultural production, representatives bodies of state power and local government.

Based on the existing problems and tasks of economic, social and environmental development, the following blocks of the platform are distinguished as the basic: a block of joint investment projects, a block of joint purchases, a block of agricultural education, personnel search and employment, a block of an eco-meteorological landscape, a marketing block of agricultural products, a block of agricultural information and news, block of rulemaking activities, block of mutual lending, block of joint activities [3].

To ensure sustainable development of agricultural production through the introduction of digital cooperation, it is necessary to plan and implement a number of projects in three environments:

- the real environment (the offline sphere, which concerns residents of rural areas, manufacturers of agricultural products, investors, suppliers of equipment, fertilizers and other things, ICT infrastructure in rural areas);

- virtual environment (the online sphere, which concerns digital technologies and software embodied in digital platforms and channels of access to them);

- institutional environment (institutions, regulatory environment, traditions and customs). 
With the interaction of real and virtual environments, taking into account institutional norms, a digital agricultural society is created, digital farming is spreading in the agricultural sector, the use of digital platforms and digital ecosystems is becoming popular, business cooperation is taking place on a digital basis.

These three interdependent environments ensure the persistence of digital transformation in the agrarian sector. In the institutional environment, there are risks of inconsistency of the regulatory framework with digital technologies. Accordingly, the problems and risks are associated with the formation of a regulatory and legal framework adequate to modern technologies, because technologies are developing much faster than changes in legislation.

In the real environment, which characterizes the existing socio-economic processes, the risks relate to an increase in social tension, an increase in the monopoly concentration of economic power in a real environment through digitalization, a discrepancy between the education system and the skills acquired during training with the level and capabilities of modern technologies $[4,5,6]$.

Accordingly, in a virtual environment (online sphere), risks relate to cybersecurity and competition with specialized digital platforms (see Table. 1).

Table 1. Risks related to digital environments

\begin{tabular}{|l|l|}
\hline \multicolumn{1}{|c|}{ Environment } & \multicolumn{1}{c|}{ Related risks } \\
\hline $\begin{array}{l}\text { Real environment } \\
\text { (offline sphere) }\end{array}$ & $\begin{array}{l}\text { - an increase in social tension (a mismatch between the education } \\
\text { system and acquired skills with the level and capabilities of } \\
\text { modern technologies, monopoly concentration of economic } \\
\text { power) }\end{array}$ \\
\hline $\begin{array}{l}\text { Virtual environment } \\
\text { (online sphere) }\end{array}$ & - cybersecurity (competition with specialized digital platforms) \\
\hline Institutional environment & $\begin{array}{l}\text { - inconsistency of the regulatory framework with digital } \\
\text { technologies }\end{array}$ \\
\hline All three environments together & - global crisis (state lagging behind digitalization processes) \\
\hline
\end{tabular}

All certain environments are threatened by a global crisis and a nationwide lag behind digitalization processes.

Taking into account certain environments for the formation of sustainable development of agricultural production on a digital basis and the risks corresponding to them, a number of directions related to the creation of an economic mechanism for digital cooperation can be proposed (see table. 2). Such directions include development of ICT infrastructure, an integral digital cooperation platform for agricultural production, the creation of an integral digital cooperation platform for agricultural production (agro-digital cooperation platforms), improvement of the regulatory framework for ensuring activities and assistance in the development of the "Integral digital cooperation platform for agricultural production", dissemination of digital knowledge and skills, attracting users to use the digital platform, creating a digital business ecosystem for agricultural production.

In a real environment, the priority is to develop ICT infrastructure in rural areas. The creation of a digital platform does not make sense without full access to the Internet [7].

Table 2. Areas of activity corresponding to the environment for the formation of sustainable agricultural development in the context of digitalization

\begin{tabular}{|l|l|}
\hline \multicolumn{1}{|c|}{ Environment } & \multicolumn{1}{c|}{ Directions } \\
\hline Real environment (offline sphere) & Development of ICT infrastructure \\
\hline $\begin{array}{l}\text { Virtual environment (online } \\
\text { sphere) }\end{array}$ & $\begin{array}{l}\text { Creation of an integrated platform for digital cooperation } \\
\text { of agricultural production (agro-digital cooperation } \\
\text { platform) }\end{array}$ \\
\hline
\end{tabular}




\begin{tabular}{|l|l|}
\hline Institutional environment & $\begin{array}{l}\text { Improving the regulatory environment to ensure activities } \\
\text { and promote the development of "integral platform for } \\
\text { digital cooperation of agricultural production" }\end{array}$ \\
\hline All three environments together & $\begin{array}{l}\text { Spread of digital knowledge and skills } \\
\text { Engaging users to use the digital platform } \\
\text { Creation of a digital business ecosystem of agricultural } \\
\text { production }\end{array}$ \\
\hline
\end{tabular}

In a virtual environment, it is necessary to accumulate funds for investment in the creation of an integral digital platform for the development of agricultural production. This platform must meet the challenges of cybersecurity. Also, a digital platform is a tool for combining a real and virtual environment, and is the basis for creation of an appropriate business

Full functioning of digital platforms is also impossible without improvement of the institutional environment. For example, the use of blockchain technology and the distribution of property rights due to it is not sufficiently regulated $[8,9]$.

Adequate interaction of the virtual and real environment requires not only the involvement of representatives of the agricultural business and the rural population, as well as investors and consumers of products from Russian cities and abroad. Ultimately, a viable ecosystem must be created that can compete in the global market.

Considering that all the described areas are interdependent and interconnected, they are available to be implemented as part of a single program aimed at creating an economic mechanism for ensuring sustainable development based on digital platforms.

The direction of "improving the institutional environment". The current regulatory framework was formed during the dominance of the industrial mode of production and the material-oriented logic of decision-making and activities, rather than the digital and network logic of creating products and services. Therefore, the introduction of modern digital and information technologies is to a certain extent restrained by the lack of an adequate regulatory framework and institutions. Consequently, the outdated regulatory framework requires improvement both on a national scale and in relation to the sphere of agricultural production. Formation of exclusive legislation, regulatory framework, institutions shall take place primarily at the general state level. It is inappropriate to develop legislation exclusively for the digitalization of agricultural production [10,11].

\section{Discussion}

Thus, the tasks of improvement of the institutional environment are:

- consolidation of the rights of Russian citizens to access the Internet at the legislative level;

- regulation of the use of blockchain technology not only as cryptocurrencies, but also as a tool for securing, distributing and redistributing property rights;

- strengthening the fight against cybercrime;

- ensuring widespread use of digital signatures;

- introduction of digital registration of legal entities and individuals;

- deregulation of restrictions on the use of digital technologies; 
- stimulation of public-private partnerships in digitalization processes;

- provision of digital education for preschool and school children, as well as for pensioners;

- maximization of cashless payments;

- harmonious implementation of online learning in classical educational processes;

- improvement of labor legislation in terms of digitalization (labor time tracking; freelance work);

Changing the institutional environment contains a number of risks and opportunities for stakeholders in rural areas (see table. 3).

Bringing the regulatory environment in line with modern digital realities will expand the opportunities for the rural population to receive online administrative services. It will have a positive impact on the creation of new, high-tech job places and an increase in wages. At the same time, conditions for expanding sales markets for the products of our own economy will be created.

Meanwhile, the process of studying and using digital legislation will require a certain amount of time from the population. To do this, it is necessary to involve workers in the field of social protection who have (have already received) the necessary knowledge.

For local authorities, the introduction of digital legislation that formalizes digitalization processes is a tool to reduce management costs, while improving the quality of administrative services. This will lead to an increase in confidence in the authorities on the part of business and the local population in rural areas.

Table 3. Risks and opportunities of institutional changes in the regulation of the digital environment for various groups of stakeholders

\begin{tabular}{|l|l|l|}
\hline \multicolumn{1}{|c|}{ Stakeholders } & \multicolumn{1}{|c|}{ Possibilites } & \multicolumn{1}{|c|}{ Risks } \\
\hline $\begin{array}{l}\text { Local community } \\
\text { (rural areas) }\end{array}$ & $\begin{array}{l}\text { l. Expanding opportunities for receiving of } \\
\text { administrative services in online mode 2. Increase } \\
\text { in the number of high-tech job places and wage } \\
\text { level 3. Expansion of opportunities for the sale of } \\
\text { products of the own economy. }\end{array}$ & $\begin{array}{l}\text { 1. The disappearance of traditional job } \\
\text { places 2. The need for time spent for digital } \\
\text { legislation study. }\end{array}$ \\
\hline $\begin{array}{l}\text { Agricultural } \\
\text { producers }\end{array}$ & $\begin{array}{l}\text { l. Expansion of sales markets 2. Expansion of } \\
\text { opportunities for joint procurement of necessary } \\
\text { products and services. 3. Opportunity to invest in } \\
\text { "digital cooperation" .4. Reducing business } \\
\text { administration costs in accordance with legal } \\
\text { requirements. }\end{array}$ & $\begin{array}{l}\text { 1. Consolidation of monopolies on the use } \\
\text { of digital platforms in the interests of certain } \\
\text { business structures through "digital } \\
\text { legislation". 2. Failure to quickly re- } \\
\text { engineer classic industrial-era business } \\
\text { processes to align with digital standards. }\end{array}$ \\
\hline $\begin{array}{l}\text { State and local } \\
\text { authority bodies }\end{array}$ & $\begin{array}{l}\text { l. Decrease in management costs at the state and } \\
\text { municipal level and at the same time ensuring of a and and } \\
\text { higher level of transparency of activities. 2. } \\
\text { Expansion of the range of services provided } \\
\text { online. }\end{array}$ & $\begin{array}{l}\text { 1. Lack of staff for modern digital } \\
\text { technologies. }\end{array}$ \\
\hline $\begin{array}{l}\text { All stakeholders } \\
\text { together }\end{array}$ & $\begin{array}{l}\text { communication between agricultural producers, } \\
\text { consumers, local communities and authorities. }\end{array}$ & $\begin{array}{l}\text { 1. Delay in digitalization processes and lack } \\
\text { of use of all of their opportunities. }\end{array}$ \\
\hline
\end{tabular}

The main risks for the government are inadequate qualifications of managers, lack of personnel with appropriate qualifications. This threatens to slow down digitalization processes and makes it impossible for society to receive digital dividends. It takes place in conditions of increased mobility of the population and 
business, and increased competition with other territories, threatens the migration of individuals and legal entities to other "digital" jurisdictions.

\section{Conclusion}

Thus, the formalization of business rules in accordance with the requirements of digitalization makes it possible to reduce the costs of business administration in accordance with legal requirements, as well as remove restrictions on the use of digital platforms to expand product markets, opportunities for joint purchases of necessary products and services, as well as investment. in "digital cooperation" [12].

The direction associated with the expansion and improvement of the quality of ICT infrastructure is a prerequisite for creating an effective platform for agro-digital cooperation and other digital platforms.

The source of funding for this area can be funds from the state budget (including the State Fund for Regional Development), local and regional budgets, funds from participants in digital cooperation, other investors as part of the public-private partnership policy.

\section{References}

1. E.F. Amirova, Kazan State Agrarian University periodical, 1(5), 5 (2007)

2. E.F. Amirova, Kazan State Agrarian University periodical, 4(38), 5 (2015)

3. Yu.A. Antokhina, A.M. Kolesnikov, E.A. Voroshin, Economics and management, 2 (160), 69 (2019)

4. V.E. Afonina, International agricultural journal, 3, 15 (2018)

5. D.R. Akhmatova, Collection of papers: Economics and innovations. Materials of research-to-practice conference, 24 (2019)

6. V.F. Vaskin, A.V. Kubiskin, Collection of papers: Design of the concept of economical development, organizational models and management systems of agro-industrial complex. Collection of scientific papers. Bryansk State Agrarian University, Educational and Methodological Board of the faculty of economics, 7(2015)

7. V.D. Goncharov, R.G. Mulmadze, V.V. Rau, Innovations and investments, 5, 33 (2015)

8. V.V. Zavarzina, Collection of papers: Informational development of Russia: current state, trends and perspectives. Collection of scientific papers of International researchto-practice conference, 56 (2019)

9. A.I Klimov, Yu.A. Mikhryachev, Collection of papers: Innovative ideas of young researchers for the agro-industrial complex of Russia. Collection of materials of the Russian scientific-to-practice conference of young scientists, 33 (2017)

10. V.L. Vasilev, A.R. Gapsalamov, E.M. Akhmetshin, T.N. Bochkareva, A.V. Yumashev, T.I. Anisimova, Entrep. Sustain, 7, 3173 (2020)

11. A. Yumashev, B. Ślusarczyk, S. Kondrashev, A. Mikhaylov, Energies, 13 (11), 2768 (2020)

12. N.V. Zakharchenko, S.L. Hasanov, A.V. Yumashev, O.I. Admakin, S.A. Lintser, M.I. Antipina, Journal of Environmental Management and Tourism, 9(3), 510 (2018) 